\title{
Faculty Member Employment of Online Platforms:
} \section{Challenges in Light of the COVID-19 Pandemic}

\author{
Rania Abedalla Abedmoneim, El Aqsa University, Palestine
}

\begin{abstract}
COVID-19 prompted the transformation of the traditional education system into a distance education system and using technological tools, including educational platforms. Online learning platforms play an important role in modern education. The objective of the research is to explore the degree of using platforms by the faculty members at Al-Aqsa University and to highlight the difficulties they face when using platforms. The research followed the qualitative and quantitative method. The instruments of the research were a semi-structured interview that included the important difficulties the faculty members faced in using platforms, and a questionnaire included the most important skills to use platforms. The results revealed that participants agreed on the most important obstacle of using educational platforms, the difficulty of access to the internet. The results of the survey indicated that the use of e-platform skills is high. The results of this study help decision makers to plan, evaluate, and implement online learning platforms in their institutions.
\end{abstract}

\section{KEYWORDS}

Al-Aqsa University, COVID-19 Pandemic, Distance Education System, E-Learning, Faculty Members, Learning Management System, Online Learning, Online Platforms

\section{.1INTRODUCTION}

Coronavirus crisis has disrupted all aspects of life worldwide, including halting the life at academic institutions. To ensure the continuity of students' learning, online educational networks and digital technologies have replaced traditional classrooms by providing web-based form of learning allowing teaching and learning to take place remotely. The switch to distance learning impacted 200 million learners across the globe distance learning in higher education saw an upsurge at the start of the coronavirus, it changed to online classroom settings and forced educators to adapt to the new way of teaching.

Alanazi and Alshaalan (2020) affirm that the most significant benefits of e-learning are its simplicity to deliver and accessibility to learning in emergency situations such as the Covid-19 pandemic. They further state that conversations about distance learning will continue even after the pandemic. Kamal et al. (2020) have also asserted that the unexpected shift to a mix of online and inclass learning is perfectly suited for the situations caused by the coronavirus crisis. As Heng and Sol (2020) have detailed, the use of online educational technology and material has generated numerous 
terms for describing technology-assisted learning, including electronic learning, online learning, distance learning, blended learning, and hybrid learning.

Higher learning education has been gone into the experimentation of e-learning within an unprecedented scale, as well as the use of all tools of e-learning and digital platforms in the educational process. Academic institutions are seeking the help of online learning so that teaching and learning processes are not hampered (Dhawan,2020). E-learning was the temporary alternative to overcome the interruption of personal teaching. This pandemic prompted the decision-makers in universities and higher education and colleges to plan, evaluate, and implement online learning platforms in their institutions. In the aftermath, situations of crisis and conflicts are the biggest hurdles in the path of education (Di Pietro, 2017).

Although teachers in many developing countries lack the skills and equipment to provide distance education effectively, most teachers and their organizations have embraced this challenge. Most universities suspended the face-to-face learning and set up some distance learning programs for students, turning teaching materials into digital format at short notice. This was a challenge as few teachers have strong digital and ICT skills (IMF, 2020).

Successful application of virtual and distance learning before the Covid-19 crisis involved teachers being trained and students being technologically-equipped and have generally taken place in noncrisis situations. Under the circumstances of the Covid-19 pandemic, given the need to act quickly, the focus has primarily been on securing access to technology. Greater attention needs to be paid to how technology and learning may be effectively integrated, including the vital role of teachers in that regard, as well as the skills that students need for distance learning (UNESCO, 2020). Universities over the past decade are gradually moving their programs online and doing away with face-to-face delivery (Bao, 2020).

Ensuring that quality learning continues in its newly adopted forms during the crisis requires that teachers have access to adequate resources and safe teaching environments and decent working conditions.

Digital platforms are considered one of the most important interactive e-learning environments, as they combine the advantages of electronic content management with the advantages of social networks. They enable teachers to publish lessons and goals, set assignments, communicate with students and implement educational activities. Furthermore, it enables teacher to make electronic tests, assign roles, exchange of ideas and opinions between teachers and students, and share digital contents. (Elhamd, 2019)

However, despite the growing usage of online platforms, there is a shortage of employing this technology, which creates an issue in itself (Abuhassna \& Yahaya, 2018; Al-Rahmi et al, 2018).

Consequently, the current research problem lies in identifying to what extent the faculty members at Al-Aqsa University use the skills of educational platforms, and highlighting the difficulties they face while using them. Through this research, a set of recommendations can be investigated as subjects of study interests that may lead to improving the experience of using educational platforms

\section{LITERATURE REVIEW}

Covid -19 is the infectious disease caused by the coronavirus. The Corona epidemic has spread dramatically all over the world, affecting all sectors of life, the most important of which is education. To prevent the outbreak of the virus, traditional face-to-face education was suspended in Palestine. As a matter of course, the Covid-19 is leaving new lesson for all spectra of life and across all sectors including the education sector. We are handling unusual methods of work, study, and etc. Virtual shopping and social media are not novel to us, nor is online education. Nevertheless, Covid-19 is stimulating the requirements to deeply investigate the prospects of virtual education. (Ziaul Hoq, 2020). 


\subsection{Digital Learning at Al- Aqsa University Against The Outbreak Of Covid-19}

Although the outbreak of Covid-19 has caused many restrictions on education, Al-Aqsa University has accepted the barriers and made every effort to provide services such as training for lecturers on digital platforms, in addition to the popularization of students and their support for distance learning during the epidemic. This found a real opportunity for the educational system to be shifted from the traditional system to a new era. Al-Aqsa University has taken some measurements in its e-learning experience including:

Moving towards e-Learning, increasing the use of Learning Management Systems, enhancing the use of soft copy of learning material, improving the collaborative work, increasing the online meetings, upgrading digital literacy, improving the use of electronic media for sharing information, better time management, emphasizing of the demand for open and distance learning (Jena, 2020).

\subsection{Online Learning System}

Online education is one of the new forms of education, and it is characterized by being completely dependent on the internet in terms of reviewing and managing curricula or educational content. the main software tool of electronic learning is Learning Management System (LMS), it is a tool for organizing distance education.

The system of distance education is the basis of any e-Learning system. The Learning Management System performs the following functions:

a. Registration of listeners, personalization, access differentiation.

b. Management of learning process, recording of learning outcomes and results of testing.

c. Integration with mechanisms of synchronous and asynchronous communication.

d. Integration with external information systems.

Using means of developing learning content, educational materials and tests are developed, then they are included in the database of the Learning Management System. Kerimbayev,et, al.,(2017).

In an era of growing digitalization of higher education and adult training, however, learning environments become increasingly accessible online. Students can thus access digital learning material or attend technology-enhanced training classes from virtually any place worldwide.

This is confirmed by the results of Burac, et al (2019) study which indicated that different Instructors e-learning had aided them to be more effective in their teaching strategy. Many Instructors point out that e-learning had helped them to prepare their teaching and learning scheme. Also, they used this application to prepare their presentational tool to be more effective in giving lessons and learning materials to their students. E-learning tools also aid the instructor in strengthening the interface between learners and lectures.

A research (Di Xu and Ying Xu,2019) on this topic suggestive that online education can indeed expand access to college. The convenience of online learning is particularly valuable to adults with multiple responsibilities and highly scheduled lives; thus, online learning can be a boon to workforce development, helping adults return to school and complete additional education that could otherwise not fit into their daily routines.

The empirical results of the Fengliang (2018) study shows that, distance higher education can significantly improve learners' income. For distance junior college learners, the increase is about $30 \%$ to $40 \%$, and for distance undergraduate learners the increase is about $50 \%$ to $60 \%$. This reveals that distance higher education is a thoroughly valuable human capital investment.

The results of a study by Bahasoan,et, al. (2020) concluded that the online learning system conducted during the Covid-19 pandemic is effective and inefficient. Effectively implemented 
because of the conditions that require online study and inefficient because the costs incurred more when compared with offline lectures.

\subsubsection{Online Learning Platforms}

An online learning platform is a space or portal filled with educational content and/or live instruction on a particular subject or many different topics. Such platforms - also referred to as "e-learning"

(https://www.idtech.com/blog/what-is-an-online-learning-platform)

\subsubsection{Examples of Online Learning Platforms}

There are various types of online learning, taking a variety of forms and setups, and differing between industry, offerings, and more features.

Some of the best online learning platforms are Coursera, Skillshare, Udemy, Codecademy, Edx, Pluralsight, and Future Learn and Moodle. This study was based on the Moodle platform.

\subsubsection{Online Moodle Platform}

Moodle platform is a pioneer system of e-learning, which is considered one of the best e-learning environments. It gains wide fame around the world as it is used by a large number of educational and academic institutions around the world. What distinguishes the Moodle platform is that it is a free and open-source platform. It gives a free access to anyone or institution to training courses and learning resources once they register on the website of the platform. Moodle platform is provided with the following functions: Kerimbayev,et, al.,(2017)

a. Asynchronous communication, that is forums, bulletin boards, electronic mail;

b. Synchronous communication, that is voice and computer chat, videoconferences, sharing of software products, virtual audience

(Mpungose,2020) asserts that formal Moodle platforms are made up of curriculum signals, such as objectives, hardware resources, assessment of learning, instructor, financial access, days, face-toface learning, content, and content-centered activities. This is confirmed by a study of (Taylakov,et al) 2020, which assumes that creating an opportunity for students to take an interest in learning; allows students to develop their professional competence; allows the quality of education and the level of education of students to increase; increases the social and professional preparation of students;

In a study conducted by (Kerimbayev,et al,2020), the authors tried to demonstrate how the LMS Moodle platform helps arrange e-learning, conduct lessons in electronic classrooms, take online courses, and conduct synchronous and asynchronous learning. The developed online tasks allowed the monitoring of the students' progress in all educational activities.

\subsection{Barriers of E-Learning}

Many teachers may encounter various difficulties or barriers while using e-learning during the pandemic of Coronavirus. These difficulties are also known as 'barriers'(Almanthari.2020). Institutionlevel barriers of educational institutions relate predominantly to hardware and software availability, access to the internet according to the institution policy. Teachers considered time to prepare lessons, textbooks and lack of technical support as major barriers (Bingimlas, 2009). Regarding student level barrier, this included students' inadequate e-learning skills (Assareh \& Bidokht, 2011), student's lack access to technology infrastructure and internet connection, and students' lack of motivation to use e-learning " barriers of e-Learning can include a number of both material and nonmaterial issues. Technology and internet accessibility and lack of an e-learning curriculum and assessment tools, to evaluate student growth effectively, limit what teachers can teach. Moreover, motivation to online learning, confidence in using e-learning technology, and teachers' attitudes to online instruction affect 
the learning process and if the learners could receive a satisfied learning. All these barriers should be considered when teachers and students are forced to immediately adjust a different mode of teaching and learning due to an event such as a pandemic" (Almanthari,et, al.,2020)

The main objective of the research is to explore the degree of using distance learning platforms by the faculty members at Al-Aqsa University, Palestine, and highlighting the difficulties they face while using e-learning in the pandemic of Coronavirus.

The research questions are:

RQ1. What is the degree of using remote-digital platforms by faculty members at Al-Aqsa University during the Covid-19 pandemic?

RQ2. Are there statistically significant differences in the degree of use of digital platforms from the perspectives of faculty members due to the variables of (gender, educational experience, specialization, academic degree)?

RQ3. What are the main difficulties faculty members faced in using e-learning during the Covid-19 pandemic?

\section{RESEERCH METHODOLOGY}

For the purpose of the study, the researcher followed the qualitative and quantitative method. Quantitative method is the descriptive method which it relies on studying the phenomenon as it exists in reality. The researcher developed an online survey to collect data from the targeted faculty members at Al-Aqsa University as participants in this study. An online survey is one of the best cost-cutting means when conducting a study, as well as an effective way to obtain reliable data from Internet users. The aim of this study was to ascertain the degree of using the online educational platforms by the faculty members at Al-Aqsa University adopted by all higher education institutions as a result of Covid-19 pandemic.

\subsection{Research Instruments}

Data was collected for the purposes of the current study by a quantitative instrument (a survey) and a qualitative instrument (interview). The survey was divided into two sections. The first section included demographic data regarding faculty members including: gender, educational experience, specialization, and academic degree. The second section included a 34-item questionnaire which categorized skills of using digital platforms into four domains, including computer and internet usage skills, basic skills of using Moodle e-learning platform, inclusion of Moodle system activities, and the faculty members' barriers with e-learning issues.

The participants rated the 34 items to the extent they agree with. Each statement using a 5-point Likert scale ranging from 1 (very large) to 5 (non-existent). The criterion of assessing the degree the faculty members expressed their possession of the skills of using digital platforms was based on the following: (1.00 - 2.60 as Weak; $2.61-3.40$ as Moderate; 3.41- 5.00 as Strong). The percentage was calculated according to the following equation: The highest value - The lowest value. In the present research, the highest value was 5; the lowest value was 1 . Thus, the percentage was calculated as follows: $5 / 5-1 / 5=0.80$.

To ensure the validity of the survey, it was presented to 4 specialized arbitrators, the four arbitrators approved the validity of the survey which consisted of 34 paragraphs as it was well-prepared as it is in its final format. To analyze data, independent T-test was applied. Frequencies and percentages were computed. Cronbach's Alpha (reliability) was also determined for all items of the survey. The reliability ratio (81\%) was a great value, which confirms that the scale has a great deal of reliability. To implement the qualitative method, the sample was purposely chosen from the available faculty 
members. To implement the qualitative curriculum, an interview was conducted with (15) participants to elicit answers to the following question:

"What are the most important difficulties facing the faculty member in using the Moodle e-learning platform?" The validity of the tool was verified by presenting the question to the specialists.

\subsection{Procedures of Data Collection}

For the purpose of the data collection, the researcher developed an online questionnaire using google forms. The electronic questionnaire has been adapted according to the uses of e-learning platforms. It carried out five main domains, they are: basic information, computer and internet usage skills, basic skills of using the Moodle e-learning platform, inclusion of Moodle system activities. The questionnaire consisted of 34 Likert scale scanning items, categorized into five main domains. The researcher applied the questionnaire to the participants, who share online education, via their emails. Data were collected over a period about two months, from faculty members at Al-Aqsa University. The questionnaire took about 5 minutes to be answered. A bi-weekly reminder strategy was used to remind participants who did not answer the questionnaire. (80) questionnaires were distributed online, (65) of them were answered; However, (60) questionnaires were applied because (5) questionnaires remained incomplete or were wrongly filled out. This refers to a $(75 \%)$ response rate. Creswell \& Poth (2016) indicated that any study with a response rate of (50\%) and above was suitable for analysis. Accordingly, the response rate of $(75 \%)$ was good. Results were scored according to a 5-point Likert scale. The range was from very large to non-existent. The average score was used to assess faculty responses for each dimension.

The interview was used to identify the barriers that faced the faculty members in using e-learning by asking 15 participants the question "What barriers did you face while using e-learning?"

\subsection{Sampling}

The study population was the faculty members at Al-Aqsa University who participated in remote teaching via electronic platforms in Palestine. The study population consisted of (418) faculty members. The sample consisted of (76) participants divided into two groups, the first group consisted of ((61 participants for the survey and the second group consisted of (15) participants for the interview.

\subsection{Demographic Background of participants}

\subsection{Data Analysis}

The data were analyzed by frequency of common responses of faculty members and reported in

Table 1. Gender distribution of the study sample

\begin{tabular}{|l|l|l|l|l|}
\hline Cumulative Percent & Valid Percent & Percent & Frequency & \\
\hline $57.3 \%$ & $57.3 \%$ & $57.3 \%$ & 35 & Male \\
\hline $100 \%$ & $42.7 \%$ & $42.7 \%$ & 26 & Female \\
\hline & $100 \%$ & $100 \%$ & 61 & Total \\
\hline
\end{tabular}

percentages after they were collected via an online survey. Demographic data were obtained using the Likert scale and were reported in percentage of the response of the faculty members.

To analyze the data of the interview, Grounded theory method was adopted, which is a systematic methodology that includes building theories through the systematic collection and analysis of data. The study that uses the rooted theory begins with a question. Once qualitative data is collected (Allan, 
Table 2. Scientific specialization of the study sample

\begin{tabular}{|l|l|l|l|l|}
\hline Cumulative Percent & Valid Percent & Percent & Frequency & \\
\hline $47.5 \%$ & $47.5 \%$ & $47.5 \%$ & 29 & Humanitarian \\
\hline $100 \%$ & $52.5 \%$ & $52.5 \%$ & 32 & Sciences \\
\hline & $100 \%$ & $100 \%$ & 61 & Total \\
\hline
\end{tabular}

Table 3. Experience categories of the of the study sample

\begin{tabular}{|l|l|l|l|l|}
\hline Cumulative Percent & Valid Percent & Percent & Frequency & \\
\hline 57.4 & 57.4 & 57.4 & 15 & Less than 5 years \\
\hline 75.4 & 18 & 18 & 11 & Between 5-10 \\
\hline 100 & 24.6 & 24.6 & 35 & more than 10 years \\
\hline & 100 & 100 & 61 & Total \\
\hline
\end{tabular}

Table 4. Academic Degree of the of the study sample

\begin{tabular}{|l|l|l|l|l|}
\hline Cumulative Percent & Valid Percent & Percent & Frequency & \\
\hline 18 & 18 & 18 & 11 & Professor and Co-professor \\
\hline 57.4 & 39.3 & 39.3 & 24 & Assistant Professor \\
\hline 100 & 42.6 & 42.6 & 26 & M.A. \\
\hline & $100 \%$ & $100 \%$ & 61 & Total \\
\hline
\end{tabular}

2003), and while the researcher reviews the data collected, ideas or concepts or recurring elements emerge which were collected from the interviews. The results were presented through the compilation of common difficulties, and some comments from the interviewers that include some ideas for the interview question, as it is shown in the results and discussion part.

\section{RESULTS}

The research results were discussed in detail based on the questions asked. The purpose of the study was to investigate the degree of employment of online education platforms by the faculty members and barriers they face in e-learning at Al-Aqsa University in Palestine during Covid-19 pandemic.

RQ1. What is the degree of using remote-digital platforms by faculty members at Al-Aqsa University during the Covid-19 pandemic?

In order to answer this question, the Mean scores and standard deviations of the responses of the study sample were calculated according to the paragraphs related to the four areas of the study survey and the survey as a whole as it is shown in table 5 .

Table (5) indicates that the degree of use of electronic platforms, from the point of view of faculty members at Al-Aqsa University is high with mean scores (3.67) and a standard deviation (0.53) according to the standard adopted in classifying the degree of employment of educational platforms. 
Table 5. Mean scores, standard deviations and the degree of responses of the sample members to the paragraphs of the questionnaire fields.

\begin{tabular}{|l|l|l|l|}
\hline Doman & Mean Score & S D. & Degree of employment \\
\hline Computer and Internet use skills & 3.76 & .59 & Strong \\
\hline Create digital content & 3.31 & 0.67 & Strong \\
\hline Basic skills of the Moodle system & 4.16 & .0 .67 & Strong \\
\hline Inclusion of Moodle System activities & 3.72 & 0.66 & Strong \\
\hline Total & 3.67 & 0.53 & Strong \\
\hline
\end{tabular}

As for the axes, they all came to a large extent, and this is attributed to the Covid-19 pandemic which has changed the way how several people receive and impart education. Teachers have become habitual to traditional methods of teaching in the form of face-to-face lectures. Therefore, they hesitate in accepting any change. But due to this crisis, there is an absolute necessity of using electronic learning, this is confirmed by the study of Dhawan (2020) that we have no other alternative left other than adapting to the healthy situation and accepting the change. It will be beneficial for the education sector and could bring a lot of surprising innovations, the faculty has to change their mindset towards the virtual classroom and adopt technology for the betterment of students. (Shenoy, et, al., 2020).

This result is consistent with the study of Al-Rashidi (2019), Ayebi- (2017), and Lomovtseva, \& Korobeynikova, (2020).

RQ2.Are there statistically significant differences in the degree of use of digital platforms from the perspectives of faculty members due to variables of (gender, educational experience, specialization, academic degree)?

1-To find out if there are statistically significant differences at $(0.05)$ between the responses of the study sample members with different gender variables, an Independent Samples T-test was adopted for the independent sample and the results were as shown in table (6).

Table 6. Shows the results of the independent data T-test for the significance of the differences between the arithmetic averages of the responses of the study sample individuals to the items of the study tool according to the gender variable.

\begin{tabular}{|c|c|c|c|c|c|c|}
\hline Doman & Gender & No & Average & SD & $\mathbf{F}$ & sig \\
\hline \multirow[t]{2}{*}{ Computer and Internet use skills } & male & 35 & 3.75 & 0.61 & \multirow[t]{2}{*}{.001} & \multirow[t]{2}{*}{.979} \\
\hline & female & 26 & 3.77 & 0.58 & & \\
\hline \multirow[t]{2}{*}{ Create digital content } & male & 35 & 3.42 & 0.68 & \multirow[t]{2}{*}{.018} & \multirow[t]{2}{*}{.892} \\
\hline & female & 26 & 3.16 & 0.65 & & \\
\hline \multirow[t]{2}{*}{ Basic skills of the Moodle system } & male & 35 & 4.13 & 0.72 & \multirow[t]{2}{*}{.143} & \multirow[t]{2}{*}{.707} \\
\hline & female & 26 & 4.19 & 0.63 & & \\
\hline \multirow[t]{2}{*}{ Inclusion of Moodle System activities } & male & 35 & 3.69 & 0.64 & \multirow[t]{2}{*}{.583} & \multirow[t]{2}{*}{.448} \\
\hline & female & 26 & 3.75 & 0.71 & & \\
\hline \multirow[t]{2}{*}{ Total } & male & 35 & 3.69 & 0.54 & \multirow[t]{2}{*}{.187} & \multirow[t]{2}{*}{.667} \\
\hline & female & 26 & 3.65 & 0.53 & & \\
\hline
\end{tabular}


Table (6) shows that there is no difference between the average grades of faculty members on employing educational platforms at Al-Aqsa University during the Covid-19 pandemic due to the gender factor, as the average of male faculty members was (33), and the average grades of female faculty members (27). The value of (F) was equal to (. 187) and it is not statistically significant. The lack of gender differences among the faculty members in the use of educational platforms is attributed to the fact that educational platforms and technology are available to all faculty members of both genders at the university. They are all aware of its importance in the educational process and consider it a solution to the problem of discontinuation of physical attendance at the university during the pandemic. In addition, the faculty members received training courses conducted by the university during the pandemic, especially for developing the skills of using learning platforms for both genders without discrimination.

2- To determine if there are statistically significant differences at (0.05) between the responses of the individuals of the study sample according to the specialization variable (human / scientific) Independent Samples T-test was adopted. The independent sample and the results came as shown in table (7)

Table 7. shows the results of the independent data T-test for the significance of the differences between the arithmetic averages of the responses of the study sample individuals to the items of the study tool according to the variable of specialization (human / scientific)

\begin{tabular}{|c|c|c|c|c|c|c|}
\hline Doman & Specialization & No & Average & SD & $\mathbf{F}$ & Sig \\
\hline \multirow[t]{2}{*}{ Computer and Internet use skills } & Human & 29 & 3.83 & 0.61 & \multirow[t]{2}{*}{0.02} & \multirow[t]{2}{*}{0.884} \\
\hline & Science & 32 & 3.69 & 0.58 & & \\
\hline \multirow[t]{2}{*}{ Create digital content } & Human & 29 & 3.35 & 0.62 & \multirow[t]{2}{*}{1.19} & \multirow[t]{2}{*}{0.279} \\
\hline & Science & 32 & 3.27 & 0.72 & & \\
\hline \multirow[t]{2}{*}{ Basic skills of the Moodle system } & Human & 29 & 4.13 & 0.66 & \multirow[t]{2}{*}{0.03} & \multirow[t]{2}{*}{0.865} \\
\hline & Science & 32 & 4.19 & 0.70 & & \\
\hline \multirow[t]{2}{*}{ Inclusion of Moodle System activities } & Human & 29 & 3.72 & 0.64 & \multirow[t]{2}{*}{0.48} & \multirow[t]{2}{*}{0.490} \\
\hline & Science & 32 & 3.71 & 0.70 & & \\
\hline \multirow[t]{2}{*}{ Total } & Human & 29 & 3.70 & 0.49 & \multirow[t]{2}{*}{0.72} & \multirow[t]{2}{*}{0.400} \\
\hline & Science & 32 & 3.64 & .0 .58 & & \\
\hline
\end{tabular}

It is evident from Table (7) that there is no difference between the average grades of faculty members on employing educational platforms at Al-Aqsa University during the Covid-19 pandemic due to the specialization factor. The average of the faculty members from the human sciences was (3.70), and the average grades of the faculty members from the applied sciences (3.64), and the value of (F) was equal to (0.72), which is not statistically significant. This is due to the fact that the electronic platforms (Moodle) are available to all faculty members at the university with different specializations and they are all aware of its importance in the educational process as they consider it a solution to the physical interruption. They are also aware of the importance of using e-learning in light of the Coronavirus pandemic, and this result is consistent with the result of study Al-Anzi (2016) 
3- To determine whether there are statistically significant differences at (0.05) between the responses of the individuals of the study sample according to the teaching experience variable, T-test for independent samples was adopted as show in table (8).

Table 8. the results of the analysis of unilateral variance to test the statistical significance of the differences between the arithmetic means of the responses of the study sample individuals to the items of the study tool according to the Teaching Experience variable.

\begin{tabular}{|c|c|c|c|c|c|c|}
\hline \multicolumn{2}{|l|}{ Doman } & \multirow{2}{*}{$\begin{array}{l}\text { Sum of Squares } \\
2.167\end{array}$} & \multirow{2}{*}{$\begin{array}{l}\text { Df } \\
2\end{array}$} & \multirow{2}{*}{$\begin{array}{l}\begin{array}{l}\text { Mean } \\
\text { Square }\end{array} \\
1.083\end{array}$} & \multirow{2}{*}{$\begin{array}{l}\mathbf{F} \\
3.271\end{array}$} & \multirow{2}{*}{$\begin{array}{l}\text { Sig. } \\
0.045 \\
\end{array}$} \\
\hline Computer and & Between Groups & & & & & \\
\hline & Within Groups & 19.209 & 58 & .331 & & \\
\hline & Total & 21.376 & 60 & & & \\
\hline \multirow{3}{*}{$\begin{array}{l}\text { Create digital } \\
\text { content }\end{array}$} & Between Groups & 0.348 & 2 & .174 & 0.370 & 0.692 \\
\hline & Within Groups & 27.240 & 58 & .470 & & \\
\hline & Total & 27.588 & 60 & & & \\
\hline \multirow{3}{*}{$\begin{array}{l}\text { Basic skills of the } \\
\text { Moodle system }\end{array}$} & Between Groups & 0.824 & 2 & .412 & 0.878 & 0.421 \\
\hline & Within Groups & 27.219 & 58 & .469 & & \\
\hline & Total & 28.043 & 60 & & & \\
\hline \multirow{3}{*}{$\begin{array}{l}\text { Inclusion of Moodle } \\
\text { System activities }\end{array}$} & Between Groups & 0.598 & 2 & 0.299 & 0.655 & 0.523 \\
\hline & Within Groups & 26.455 & 58 & 0.456 & & \\
\hline & Total & 27.052 & 60 & & & \\
\hline \multirow[t]{3}{*}{ Total } & Between Groups & 0.524 & 2 & 0.262 & \multirow[t]{3}{*}{0.907} & \multirow[t]{3}{*}{0.409} \\
\hline & Within Groups & 16.739 & 58 & 0.289 & & \\
\hline & Total & 17.262 & 60 & & & \\
\hline
\end{tabular}

The table shows that the value of $(\mathrm{F})$ for the fields (second, third and fourth) came respectively $(0.370,0.878,0.655)$ and the total calculated value of $\mathrm{F}$ came $(0.907)$ all of these values are not statistically significant, i.e. there are no differences between faculty members due to the overall degree experience factor and all areas except the first. The reason for this result is that the faculty members possess expertise and technological skills as a result of the courses conducted by the university or courses that they have acquired outside the university in addition to their previous experience and technology they used in scientific research. As it is a requirement of promotion, the faculty members are required to work constantly on the scientific research. The same is true with the technological skills, the educational policy of universities for professional, scientific and technological development requires the faculty members to be in a sustained follow-up to catch up with technology. Accordingly, lecturers are forced to follow up the technology developments constantly, including educational platforms. The results of questionnaire in table (8) are consistent with Al-Shehri (2017) and Al-Rashidi (2019)

The results indicate that there are statistically significant differences on the first field as it is shown in the table. The value of F (3.271) is a statistically significant which means that there are differences between faculty members on the first field (skills of computer and use of internet) due to the experience variable. To find out the differences of the statistical significance on this ax field, a comparison was made between the critical difference for each of the pairs of averages and the difference of the two averages related to them. After calculating the Scheffe Test for the differences between the mean scores on the axis according to the experience variable, the results came as shown in Table (9) 
Table 9. Scheffe Test results to find out the differences between the mean scores in the fields of the survey according to the specialization variable.

\begin{tabular}{|l|l|l|l|l|l|}
\hline Doman & Experience(I) & Experience (J) & $\begin{array}{l}\text { Mean Difference } \\
\text { (I-J) }\end{array}$ & Std. Error & Sig. \\
\hline $\begin{array}{l}\text { Computer and } \\
\text { Internet use } \\
\text { skills }\end{array}$ & \multirow{2}{*10}{} & $\mathbf{5 - 1 0}$ & $\mathbf{0 . 0 8 8 8 6}$ & $\mathbf{0 . 1 9 8 9 3}$ & $\mathbf{0 . 9 0 5}$ \\
\cline { 2 - 6 } & $<5$ & 0.45219 & 0.17760 & 0.046 \\
\cline { 2 - 6 } & \multirow{2}{*}{$5-10$} & $>10$ & -0.08886 & 0.19893 & 0.905 \\
\cline { 2 - 6 } & $<5$ & 0.36333 & 0.22845 & 0.290 \\
\cline { 2 - 6 } & \multirow{2}{*}{} & $>5$ & -0.45219 & 0.17760 & 0.046 \\
\cline { 2 - 6 } & & $5-10$ & -0.36333 & 0.22845 & 0.290 \\
\hline
\end{tabular}

The results of Table (9) indicate that there are statistically significant differences between faculty members with experience greater than 10 years and less than 5 years, with an average difference of (.36333) in favor of experience greater than 10 years. That means the use of faculty members whose experience more than 10 years possess the skills of the first axis (skills of computer and use of internet). This can be attributed to the training courses that these people obtained, whether inside or outside the university in addition to their great practical experience in the field of scientific research which needs technological skills. It is also attributed to the members of the teaching staff, who had little experience or were busy completing their higher studies and preparing scientific courses, which decreased their interest in modern technologies.

This result is consistent with the results of the study of Al-Anzi (2017) and differs with the study of Al-Rashidi (2020).

4- To find out if there are statistically significant differences at (0.05) between the responses of the study sample with the difference in the academic degree variable, one-way analysis (ANOVA) was adopted. The results came as it is shown in table (10)

The results shown in table (10) indicate that there are no statistically significant differences between the averages of the responses of the members of the study sample due to the variable of the academic degree. Whereas the calculated value of (F) of the faculty members reached (.505) which is not statistically significant. This is attributed to the reason that the educational platforms are available to all faculty members with different degrees. This explains that all faculty members are aware of the importance of e-learning during the Coronavirus pandemic in addition to their interest in e-learning during Coronavirus pandemic regardless of their academic degree. This interest may encourage the administration of Al-Aqsa University to develop the e-learning system by upgrading the infrastructure of e-learning in terms of technical support and servers. In addition to developing the capacities and technological skills of the faculty members through series of training courses in the skills of using Moodle platforms and mandating all faculty members to use the Moodle platform in distance learning regardless of their academic degree. It may also be interpreted that Al-Aqsa University plans to activate the distance learning to develop the capabilities of its all-faculty members towards possessing the skills of educational platforms regardless their academic rank.

RQ3. What are the main difficulties faculty members faced in using e-learning during the Covid-19 pandemic? 
Table 10. results of the (ANOVA) analysis to test the statistical significance of differences between the computational averages of the responses of the study sample members to the paragraphs of the study tool by the degree variable scientific rank

\begin{tabular}{|c|c|c|c|c|c|c|}
\hline \multicolumn{2}{|l|}{ Doman } & $\begin{array}{l}\text { Sum of } \\
\text { Squares }\end{array}$ & df & $\begin{array}{l}\text { Mean } \\
\text { Square }\end{array}$ & $\mathbf{F}$ & Sig. \\
\hline \multirow{3}{*}{ Computer and Internet use skills } & Between Groups & 1.329 & 2 & .665 & 1.923 & 0.155 \\
\hline & Within Groups & 20.047 & 58 & .346 & & \\
\hline & Total & 21.376 & 60 & & & \\
\hline \multirow{3}{*}{ Create digital content } & Between Groups & .905 & 2 & .453 & .984 & 0.380 \\
\hline & Within Groups & 26.682 & 58 & .460 & & \\
\hline & Total & 27.588 & 60 & & & \\
\hline \multirow{3}{*}{$\begin{array}{l}\text { Basic skills of the Moodle } \\
\text { system }\end{array}$} & Between Groups & .017 & 2 & .009 & .018 & 0.982 \\
\hline & Within Groups & 28.026 & 58 & .483 & & \\
\hline & Total & 28.043 & 60 & & & \\
\hline \multirow{3}{*}{$\begin{array}{l}\text { Inclusion of Moodle System } \\
\text { activities }\end{array}$} & Between Groups & .180 & 2 & .090 & .194 & 0.824 \\
\hline & Within Groups & 26.873 & 58 & .463 & & \\
\hline & Total & 27.052 & 60 & & & \\
\hline \multirow{3}{*}{ Total } & Between Groups & .296 & 2 & .148 & .505 & 0.606 \\
\hline & Within Groups & 16.967 & 58 & .293 & & \\
\hline & Total & 17.262 & 60 & & & \\
\hline
\end{tabular}

Based on the results of the interview, it was found that the faculty members face some obstacles in using the educational platforms, that $85 \%$ of the faculty members face the problems of power outages and poor internet network. This is confirmed by a study of (Gyimah,2020) It was identified that technological innovation has become very relevant as in e-learning. Another finding was that numerous developing countries are still encountering barriers in enjoying e-learning as internet connectivity is a major problem (Bahasoan, et.al,2020). It can be concluded that the online learning system conducted during the Covid-19 pandemic is effective and efficient. Effectively implemented because of the conditions that require online study and inefficient because the costs incurred more when compared with offline lectures. Costs incurred mainly to buy internet quota to keep up with online lectures. Bao (2020), and Filius et al. (2019) argue that going entirely online requires significant planning and investments from all sectors. So, if the university has not hitherto taken the students and instructors through an online teaching training, and may not have enough resources including recording platforms both on campus and at home to get the instructor to record and present the work in a manner that can be accessed by students, then the online plan ends right here (Yang \& Li, 2018). While $60 \%$ of the faculty members were able to reach their students online and communicate with them, there was a slow interaction of students with e-learning. We are trying to spread them out and stimulate a weak response. This is what confirmed in a study by (Wahyudi, et.all,2020).

This result is consistent with the result of the study conducted by (Almanthari, 2020) The most significant barriers, the faculty members faced were the student level, student lack of knowledge and skill in e-learning use, and their poor knowledge of access to devices and internet connection. Student barriers had a strong correlation with the level of the students.

While $40 \%$ of the faculty members faced some difficulties because they did not receive appropriate training on digital platforms. This may because they were unbale to attend the virtual training conducted by the university. A faculty member stated, "I was not able to attend any virtual training session of the sessions held by the university" he added "The training time was not appropriate for 
me, sometimes, after the training session started, the electricity was cut off." This was confirmed by a study (Abu shakhidem, 2020), which revealed the most important obstacles to e-learning that faculty members at Palestine Technical University "Khadouri" did not receive sufficient training to lead the e-learning process in a crisis.

While $30 \%$ of the faculty members found that the sudden shift from traditional to electronic education due to the pandemic caused a shock to teachers and students and constituted an obstacle in the use of educational platforms. Some of them indicated "the pandemic of Covid-19 and e-learning have caused two shocks at a time ". The is confirmed by the study of (Yulia, 2020) which revealed that the pandemic of Covid-19 has affected the reshaping of education in Indonesia, where the traditional method of education was replaced with e-learning because it supports learning from home and thus reduces the mixing of individuals with each other, and reduces the outbreak of the virus.

While $60 \%$ found it difficult to use e-learning skills due to not previously possessing digital skills. Some of them indicted "I do not have a previous knowledge in using technology". Therefore, professional training of digital skills is very important.

Online teaching is an essential part of such professional qualification but not the only one. Universities, now more than ever, should invest in faculty members' professional development to be updated on effective pedagogical methods whether they use online technologies or not (Rapanta,et, al.,2020).

Boczkowska et al. (2018) recommended that e-learning programs are necessary systems of continual education, so the educational system needed to be developed and additional work needs to be directed to the enhancement of online learning programs.

One of the most important difficulties that a faculty member face is evaluation and tests. The rate of cheating is high and difficult to control in spite of the restrictions applied on electronic tests, but the cheating rate remains high. This is confirmed by a study (Munoz and Mackay 2019) which referred that assessment can possibly be considered the most challenging part of the transition to distance learning for an institution used to conduct face-to-face, oral or written exam, as the control shift towards the students makes it hardly possible to ensure that students are not cheating.

Challenges to the online environment during an emergency may delay the adoption of technologyenabled education (Chiasson, et, all.,2015).

The difficulties faced by the faculty members are due to the fact that Al-Aqsa University is one of the universities that adopt face-to-face learning, and did not have in its plans the adoption of e-learning. It suddenly switched to e-learning, the matter which put the learning process in some barriers and difficulties while using the e-learning.

Most of the lecturers are accustomed to the traditional face-to-face teaching and learning method (Ananga \& Biney, 2017). Hence, as beginners, they will likely face some barriers. According to Toepoel (2017), In addition to the fact that e-learning requires an infrastructure of networks, hardware, and software and the purchase of special programs for the university to ensure the participation of the largest number of students in e-learning. Since e-learning was imposed on the university suddenly as a result of the Covid-19 pandemic, the faculty members were communicating with students through the available channels of communication, which are weak.

The results of this question match with the results of the study of (Abu Shkheidem, 2020) and the study of (Draissi, Yong, 2020), which revealed that the response to the outbreak of COVID-19 and the implementation of distance education in Moroccan universities was facing some difficulties and challenges for both teachers and students.

In contrast, the results of this question conflicted with the results of study of (Basilaia, Kvavadze, 2020) which revealed that the experience of transitioning from school education to online learning during the pandemic of Coronavirus in Georgia was successful. E-learning is a structured process aimed at achieving educational outcomes using technological means which provide voice, image, film and interaction between the learner and the educational content and activities. 


\subsection{CONCLUSION}

This study examined the extent to which faculty members use online platforms and the difficulties they face in using e-learning. According to this study, it was found that the skills of faculty members of using the educational platforms is high. It is also found that they use educational activities effectively on the Moodle and distance learning platforms. The results of the study also revealed the faculty members face some difficulties while using e-learning platforms.

The impact of Covid-19 on the traditional learning method of academic institutions around the world including schools, colleges and university, led the administrations of these institution to use the distance learning as an alternative method to resume the educational process. Although online learning has proven its efficiency in protecting the health of students as it limited the physical existence at the educational institutions. But from the faculty members point of view, the Coronavirus pandemic is not as effective as traditional learning. Online learning cannot achieve the desired results in developing countries like Palestine, where the vast majority of teachers cannot access to the internet due to technical and monetary issues.

Aside from the technical and financial problems of power cuts and poor internet, faculty members also reported some other difficulties such as lack of interaction with students, response time, and lack of traditional socialization in the classroom. Lack of socialization on campus caused difficulties for students to carry out group projects in distance learning.

Faculty members indicated that some students are not familiar with the e-learning system, and others do not constantly follow the university's electronic platform. It requires great effort and time in preparing digital contents, following and correcting activities. In this regard, some lecturers showed a lack of experience in this field, that does not mean that lecturers lack the readiness to use e-learning tools but they need to be provided with the basic skills to use the computer and the internet before embarking on using e-learning. insufficient training on the e-learning platform approved by the university (Moodle), hindering students 'time for simultaneous lectures (meetings) between the lecturers.

The results of this study also indicated the necessity to provide an adequate physical infrastructure for distance learning from the Internet and servers and to purchase programs, with the need to intensify training courses for lecturers and students on digital skills and the skill of designing digital content for teachers. According to WHO instructions, we have to adjust our daily activities with Covid-19 for a period of time at least, which means educational institutions have to design appropriate and effective content, arrange effective content delivery system and provide digital literacy training for current faculty members which can help in achieving better educational outcomes.

\subsection{Limitations}

This study is limited to check the performance of faculty members. In the future, the performance of students can be investigated by similar conditions. There may be some issues and problems faced by the faculty members such as the limited access to the internet or disturbance due to low signals, the results are based solely on the views of faculty members, so including faculty opinions in future studies may help reducing the problems teachers are facing in relation to online education. In addition, this research was based in Palestine, which may be inclined by Arab culture. It indicates that the observations of this research may be culture-dependent. The results are bounded by two demographic details (i.e. gender, educational experience, specialization, academic degree). Other demographic details may have different results, accordingly.

\subsection{Recommendation of the Research}

Whereas, e-learning has become mandatory in the Covid-19 pandemic and has been approved in all universities, the researcher recommends that organizing formal training could be useful for faculty 
members with less than five years of teaching experience who are not comfortable with technology. This is sustained by Hung (2016).

Course syllabus ought to be revised to promote the use of e-learning platforms for faculty members. This is what a study recommended (Ziaul Hoq,2020)

University administration should announce lucrative incentives for faculty members to motivate them to use e-learning system.

It is recommended that Non-Governmental Organizations should work on improving the internet networks in most of the developing countries to benefit from e-learning.

Adequate training and workshop should be organized to enhance the students' and teachers' abilities of using e-learning. 


\section{REFERENCES}

Abu Shkheidem, S. S. (2020). The Effectiveness of E-Learning in Light of the Spread of the Coronavirus from the Viewpoint of Teachers at Palestine Technical University (Khadouri). The Arab Journal for Scientific Publishing, Research and Human Resources Development, 21, 365-389.

Abuhassna, H., Al-Rahmi, W. M., Yahya, N., Zakaria, M. A. Z. M., Kosnin, A. B. M., \& Darwish, M. (2020). Development of a new model on utilizing online learning platforms to improve students' academic achievements and satisfaction. International Journal of Educational Technology in Higher Education, 17(1), 1-23. doi:10.1186/ s41239-020-00216-Z

Abuhassna, H., \& Yahaya, N. (2018). Students' utilization of distance learning through an interventional online module based on Moore transactional distance theory. Eurasia Journal of Mathematics, Science and Technology Education, 14(7), 3043-3052. doi:10.29333/ejmste/91606

Al-Rahmi, W. M., Alias, N., Othman, M. S., Alzahrani, A. I., Alfarraj, O., Saged, A. A., \& Rahman, N. S. A. (2018). Use of e-learning by university students in Malaysian higher educational institutions: A case in Universiti Teknologi Malaysia. IEEE Access: Practical Innovations, Open Solutions, 6, 14268-14276. doi:10.1109/ ACCESS.2018.2802325

Al-Rashidi, A. M. (2020). The degree of employment of E-learning at Kuwait University from the point of view of faculty members at the university. IUGJEPS, 28(1). https://journals.iugaza.edu.ps/index.php/IUGJEPS/ article/viewFile/5448/2948

Al-Shehri, A. (2017). The Reality of Applying the Learning Management System Classera in the Schools of Assir Directorate. AJSRP, 7(1), 142-142.

Alanazi, A. A., \& Alshaalan, Z. M. (2020). Views of faculty members on the use of e-learning in Saudi medical and health colleges during COVID-19 pandemic. Journal of Nature and Science of Medicine, 3(4), 308-317. doi:10.4103/JNSM.JNSM_82_20

Alanezi, S. F. (2017). The Degree of Information and Communication Technology Used by Faculty Member at Shaqra University and the Obstacles to that use. Journal of Educational \& Psychological Sciences, 17(2), 175-203. doi:10.12785/jeps/170206

Allan, G. (2003). A Critique of Using Grounded Theory as a Research Method. Electronic Journal of Business Research Methods, 2(1), 1-10.

Almanthari, A., Maulina, S., \& Bruce, S. (2020). Secondary School Mathematics Teachers' Views on E-learning Implementation Barriers during the COVID-19 Pandemic: The Case of Indonesia. Eurasia Journal of Mathematics, Science and Technology Education, 16(7), 1-9.10.29333/ejmste/8240

Ananga, P., \& Biney, I. K. (2017). Comparing Face-To-Face And Online Teaching And Learning In Higher Education, MIER Journal of Educational Studies, Trends \& Practices, 7(2), 165-179. doi:10.52634/mier/2017/ $\mathrm{v} 7 / \mathrm{i} 2 / 14152$

Ayebi-Arthur, K. (2017). E-learning, resilience, and change in higher education: Helping a university cope after a natural disaster. E-Learning and Digital Media, 14(5), 259-274. doi:10.1177/2042753017751712

Bahasoan, A. N., Ayuandiani, W., Mukhram, M., \& Rahmat, A. (2020). Effectiveness of online learning in pandemic COVID-19. International Journal of Science, Technology \& Management, 1(2), 100-106.

Bao, W. (2020). COVID-19 and online teaching in higher education: A case study of Peking University. Human Behavior and Emerging Technologies, 113-115. .10.1002/hbe2

Basilaia, G., \& Kvavadze, D. (2020). Transition to Online Education in Schools during a SARS-CoV-2 Coronavirus (COVID-19) Pandemic in Georgia. Pedagogical Research, 5(4), 1-9. doi:10.29333/pr/7937

Bidokht, M. (2011). Education Barriers to E-teaching and E-learning. Procedia Computer Science, 3, 791-795. doi:10.1016/j.procs.2010.12.129

Bingimlas, K. H. (2009). Barriers to the Successful Integration of ICT in Teaching and Learning Environments: A Review of the Literature. Eurasia Journal of Mathematics, Science and Technology Education, 5(3), 235-245. doi:10.12973/ejmste/75275 
Boczkowska, K., Bakalarski, P., Sviatoslav, M., \& Leszczyński, P. (2018). The importance of e-learning in professional improvement of emergency nurses. Critical Care Innovations - Journal, 1(1), 16-24. .10.32114/ CCI.2018.1.1.16.24

Burac, M., Fernandez, J. M., Cruz, M., \& Dela Cruz, J. (2019). Assessing the impact of e-learning system of higher education institution's instructors and students [Paper presentation]. The International Conference on Information Technology and Digital Applications, Yogyakarta, Indonesia. doi:10.1088/1757-899X/482/1/012009

Chiasson, K., Terras, K., \& Smart, K. (2015). Faculty perceptions of moving a face-to-face course to online instruction. Journal of College Teaching \& Learning, 12(3), 321-240. DOI:.v12i3.931510.19030/tlc

Creswell, J., \& Poth, C. (2016). Qualitative Inquiry and Research Design: Choosing Among Five Approaches. SAGE Publications.

Dhawan, S. (2020). Online learning: A panacea in the time of COVID-19 crisis. Journal of Educational Technology Systems, 49(1), 5-22. https://journals.sagepub.com/doi/full/10.1177/0047239520934018

Di Pietro, G. (2017). The academic impact of natural disasters: Evidence from the L'Aquila earthquake. Education Economics, 26(1), 62-77. doi:10.1080/09645292.2017.1394984

Di Xu, Y. X. (2019, March 4). The Promises And Limits Of Online Higher Education Understanding How Distance Education Affects Access, Cost, And Quality. American Enterprise Institute. https://www.aei.org/ research-products/report/the-promises-and-limits-of-online-higher-education/

Draissi, Z., \& ZhanYong, Q. (2020). COVID-19 Outbreak Response Plan: Implementing Distance Education in Moroccan Universities. https://ssrn.com/abstract=358678310.2139/ssrn.3586783.

El-hamd, H. (2019). The reality of using electronic platforms by faculty members in teaching Islamic sciences. JSRE, 20(8), 436-467. doi:10.21608/jsre.2019.57263

Fengliang, L. (2018). The Expansion of Higher Education and the Returns of Distance Education in China. International Review of Research in Open and Distributed Learning, 19(4), 242-256. doi:10.19173/irrodl. v19i4.2881

Filius, R. M., Kleijn, R. A. M., Uijl, S. G., Prins, F. J., Rijen, H. V. M., \& Grobbee, D. E. (2019). Audio peer feedback to promote deep learning in online education. Journal of Computer Assisted Learning, 35(5), 607-619. doi:10.1111/jcal.12363

Gyimah, K.A. (2020). Students' Perceptions and Continuous Intention to Use ELearning Systems: The Case of Google Classroom. International Journal of Emerging Technologies in Learning, 15(11), $236-244$. .v15i11.12683<ALIGNMENT.qj></ALIGNMENT>10.3991/ijet

Heng, K., \& Sol, K. (2020). Online learning during COVID-19: Key challenges and suggestions to enhance effectiveness. Cambodian Education Forum. https://cambodianeducationforum.wordpress.com

Hung, M.-L. (2016). Teacher readiness for online learning: Scale development and teacher perceptions. Computers \& Education, 94, 120-133. doi:10.1016/j.compedu.2015.11.012

International Monetary Fund. (2020). Policy responses to COVID-19. https://www.imf.org/en/Topics/imf-andcovid19/Policy-Responses-to-COVID-19

Jena, P. K. (2020). Impact of Pandemic COVID-19 on education in India. International Journal of Current Research, 12(7), 12582-12586. http://journalcra.com/article/impact-pandemic-covid-19-education-india

Kamal, A. A., Shaipullah, N. M., Truna, L., Sabri, M., \& Junaini, S. N. (2020). Transitioning to online learning duringCOVID-19 pandemic: Case study of a pre-university centre in Malaysia. International Journal of Advanced Computer Science and Applications, 11(6), 217-223. doi:10.14569/IJACSA.2020.0110628

Kerimbayev, N., Kultan, J., Abdykarimova, S., \& Akramova, A. (2017). LMS Moodle: Distance international education in cooperation of higher education institutions of different countries. Education and Information Technologies, 22(5), 2125-2139.10.1007/s10639-016-9534-5

Kerimbayev, N., Nurym, N., Akramova, A., \& Abdykarimova, S. (2020). Virtual educational environment: interactive communication using LMS Moodle. Education and Information Technologies, 25(3), $1965-1982$. .10.1007/s10639-019-10067-5 
Liu, Z. Y., Lomovtseva, N., \& Korobeynikova, E. (2020). Online Learning Platforms: Reconstructing Modern Higher Education. International Journal of Emerging Technologies in Learning, 15(13), 4-21. doi:10.3991/ ijet.v15i13.14645

Mpungose, C. B. (2020). Is Moodle a platform to decolonise the university curriculum? Lecturers' reflections. Africa Education Review, 17(1), 100-115. doi:10.1080/18146627.2018.1479645

Munoz, A., \& Mackay, J. (2019). An online testing design choice typology towards cheating threat minimization, Journal of University Teaching \& Learning Practice, 16(3). https://ro.uow.edu.au/jutlp/vol16/iss3/5

Oxford. (n.d.). https://www.oxfordlearnersdictionaries.com/definition/american_english/barrier

Picciano, A. G. (2017). Theories and frameworks for online education: Seeking an integrated model. Online Learning, 21(3), 166-190. doi:10.24059/olj.v21i3.1225

Rapanta, C., Botturi, L., Goodyear, P., Guàrdia, L., \& Koole, M. (2020). Online university teaching during and after the Covid-19 crisis: Refocusing teacher presence and learning activity. Post Digital Science and Education, 2(3), 923-945. doi:10.1007/s42438-020-00155-y

Shenoy, V., Mahendra, S., \& Vijay, N. (2020). COVID 19 lockdown technology adaption, teaching, learning, students' engagement and faculty experience. Mukt Shabd Journal, 9(4), 698-702.

Taylakov, N. I., \& Anarbaeva, F. U. (2020). Pedagogical Features of Moodle Platform. The American Journal of Applied Sciences, 2(7), 104-107.10.37547/tajas/Volume02Issue07-17

Toepoel, V. (2017). Online survey design. In The SAGE Handbook of Online Research Methods. SAGE. doi:10.4135/9781473957992.n11

UNESCO. (2021). Global Education. https://en.unesco.org/covid19/educationresponse/globalcoalition

Wahyudi, M. (2020). Covid-19 and Portrait Learning Ber E-Learning Basis. https://republika.co.id/berita/ q8gkaa374/covid19-dan-potret-elearning-based-learning

WordNet. (n.d.). Princeton University. http://dictionary.reference.com/search?q=barrier

Yang, F., \& Li, F. W. B. (2018). Study on student performance estimation, student progress analysis, and student potential prediction based on data mining. Computers \& Education, 123, 97-108. doi:10.1016/j. compedu.2018.04.006

Yulia, H. (2020). Online Learning to Prevent the Spread of Pandemic Corona Virus in Indonesia. ETERNAL, 1(11). DOI:.v11i1.606810.26877/eternal

Ziaul Hoq M. (2020). E-Learning During the Period of Pandemic (COVID-19) in the Kingdom of Saudi Arabia: An Empirical Study. American Journal of Educational Research, 8(7), 457-464. DOI: 10.12691/education-8-7-2 